\title{
Labour market forecasts up to 2026
}

Citation for published version (APA):

Bakens, J., Bijlsma, I., Dijksman, S., Fouarge, D., \& Goedhart, R. (2021). Labour market forecasts up to 2026. ROA. ROA Fact Sheets No. 002E https://doi.org/10.26481/umarof.2021002E

Document status and date:

Published: 08/07/2021

DOI:

10.26481/umarof.2021002E

Document Version:

Publisher's PDF, also known as Version of record

\section{Please check the document version of this publication:}

- A submitted manuscript is the version of the article upon submission and before peer-review. There can be important differences between the submitted version and the official published version of record.

People interested in the research are advised to contact the author for the final version of the publication, or visit the DOI to the publisher's website.

- The final author version and the galley proof are versions of the publication after peer review.

- The final published version features the final layout of the paper including the volume, issue and page numbers.

Link to publication

\footnotetext{
General rights rights.

- You may freely distribute the URL identifying the publication in the public portal. please follow below link for the End User Agreement:

www.umlib.nl/taverne-license

Take down policy

If you believe that this document breaches copyright please contact us at:

repository@maastrichtuniversity.nl

providing details and we will investigate your claim.
}

Copyright and moral rights for the publications made accessible in the public portal are retained by the authors and/or other copyright owners and it is a condition of accessing publications that users recognise and abide by the legal requirements associated with these

- Users may download and print one copy of any publication from the public portal for the purpose of private study or research.

- You may not further distribute the material or use it for any profit-making activity or commercial gain

If the publication is distributed under the terms of Article $25 \mathrm{fa}$ of the Dutch Copyright Act, indicated by the "Taverne" license above, 


\section{LABOUR MARKET FORECASTS UP TO 2026}

Factsheet ROA-F-2021/2E

\section{EXPECTED LABOUR DEMAND UNTIL 2026 IS LOWER THAN BEFORE}

Although the recovery of employment following the Covid-19-pandemic is proceeding rapidly this and next year, the outlook for the next 6 years is less favourable than projected before the pandemic

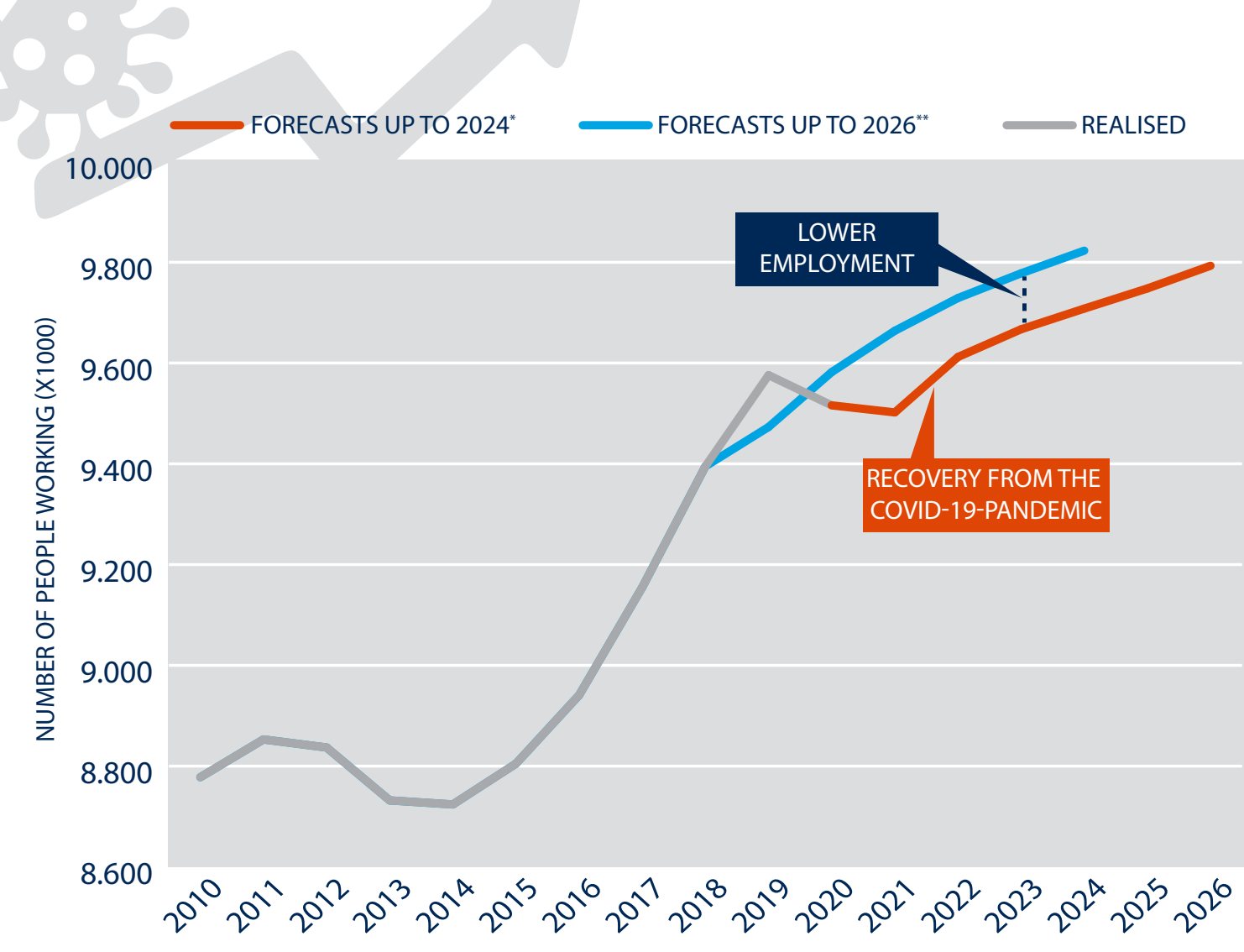

LABOUR MARKET PROSPECTS BY EDUCATION

\begin{tabular}{|c|c|c|c|}
\hline $\mathrm{MBO}_{3}$ & $\mathrm{MBO}_{4}$ & BACHELOR & MASTER \\
\hline AGRICULTURE & AGRICULTURE & $\begin{array}{l}\text { AGRICULTURE } \\
\text { AND SCIENCE }\end{array}$ & $\begin{array}{l}\text { AGRICULTURE } \\
\text { AND SCIENCE }\end{array}$ \\
\hline $\begin{array}{l}\text { ENGINEERING } \\
\text { AND ICT }\end{array}$ & ENGINEERING & $\begin{array}{l}\text { ENGINEERING } \\
\text { AND ICT }\end{array}$ & $\begin{array}{l}\text { ENGINEERING } \\
\text { AND ICT }\end{array}$ \\
\hline $\begin{array}{l}\text { ECONOMY } \\
\text { AND SOCIETY }\end{array}$ & $\begin{array}{l}\text { ECONOMY } \\
\text { AND SOCIETY }\end{array}$ & $\begin{array}{l}\text { ECONOMY } \\
\text { AND SOCIETY }\end{array}$ & $\begin{array}{l}\text { ECONOMY } \\
\text { AND SOCIETY }\end{array}$ \\
\hline $\begin{array}{l}\text { HEALTH AND } \\
\text { SERVICES }\end{array}$ & $\begin{array}{l}\text { HEALTH AND } \\
\text { SERVICES }\end{array}$ & $\begin{array}{l}\text { HEALTH AND } \\
\text { EDUCATION }\end{array}$ & $\begin{array}{l}\text { HEALTH AND } \\
\text { EDUCATION }\end{array}$ \\
\hline
\end{tabular}

JOB OPENINGS
MAJOR BOTTLENECKS FOR EMPLOYERS IN EDUCATIONAL, SCIENCE $2 \mathrm{mln}$

UNTIL 2026

More than 2 million job openings are

expected during the next six years.

The need to replace people who

(temporarily) leave the labour market

due to reasons such as retirement and

disability accounts for almost $90 \%$ of the

job openings. The remaining demand is

caused by economic growth.

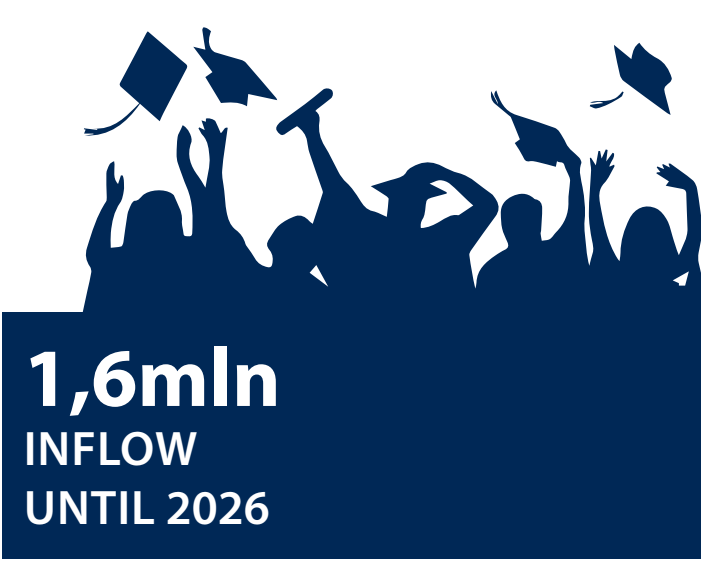

$B A D$
AND ENGINEERING, ICT AND HEALTHCARE OCCUPATIONS

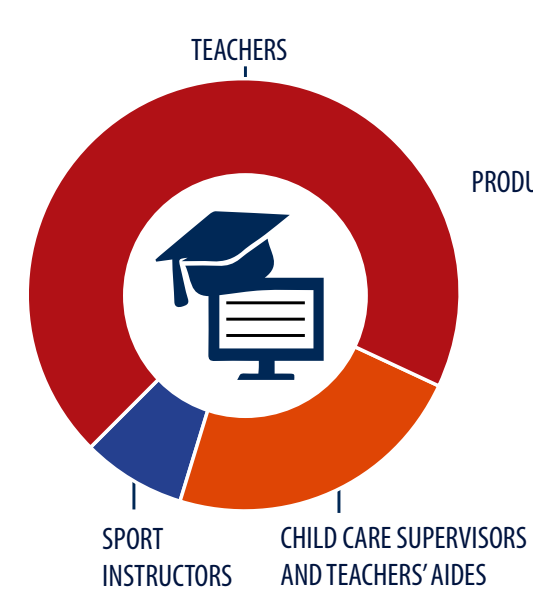

ICT PROEESSIONAL

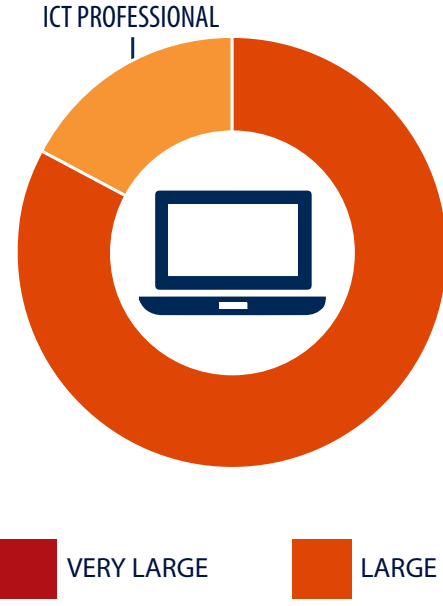

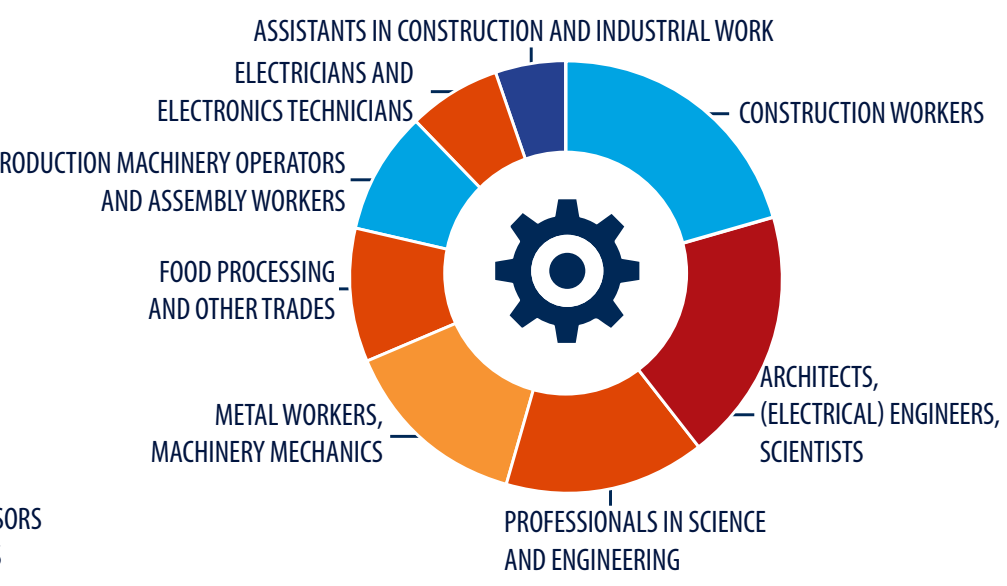

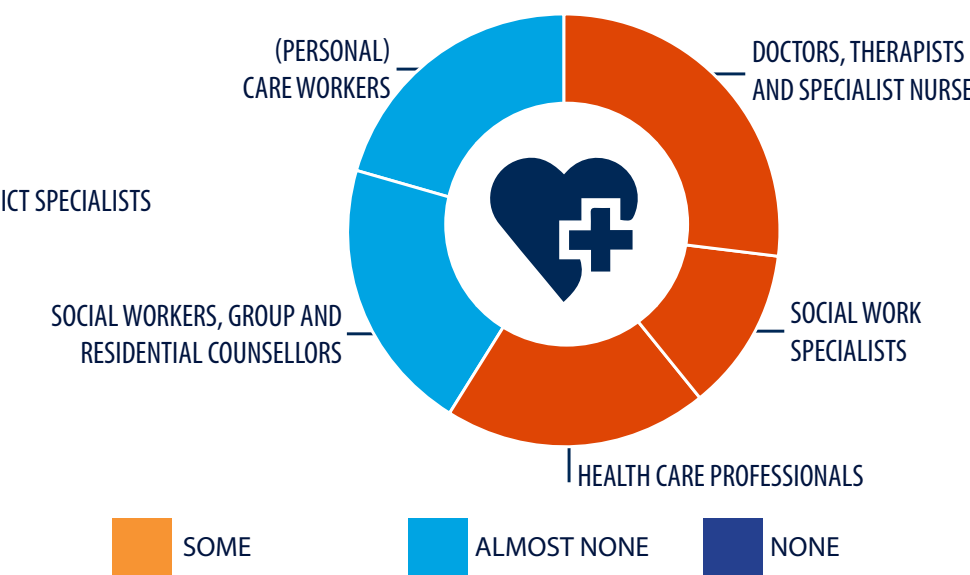

UNCERTAINTY

The forecasts are subject to increased uncertainty because the short and long-term effects of the Covid-19-pandemic on the demand and supply side of the labour market are still unclear. This concerns the effects on economic growth but also on long-term trends such as unclear. This concerns the effects on economic growth but also
automation, skills upgrading and increased flexibility of jobs.

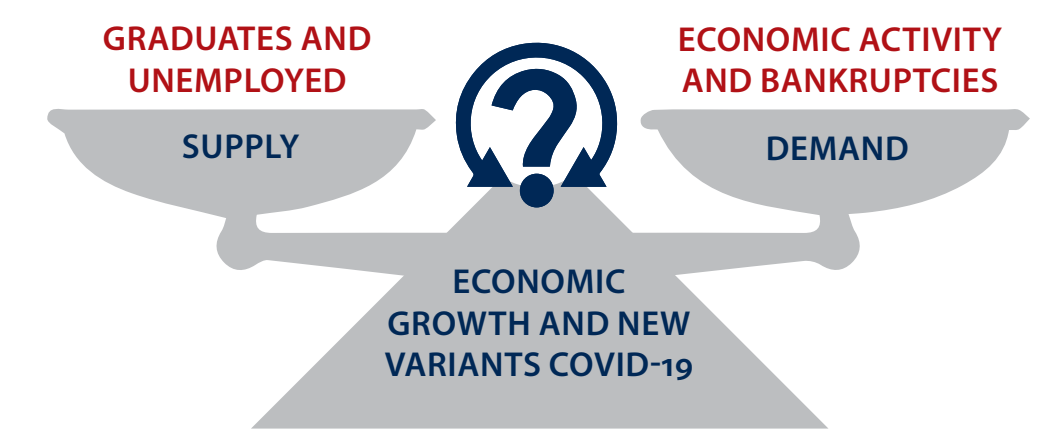

www.roa.nl 